\title{
MMP14 wt Allele
}

National Cancer Institute

\section{Source}

National Cancer Institute. MMP14 wt Allele. NCI Thesaurus. Code C49730.

Human MMP14 wild-type allele is located within $14 q 11-q 12$ and is approximately $11 \mathrm{~kb}$ in length. This allele, which encodes matrix metalloproteinase-14, plays a role in the activation of progelatinase A. The MMP14 gene is associated with the metastasis of several types of cancer including breast, gastric and laryngeal cancers. 